\title{
DESAIN PRODUK PEMBERI PAKAN IKAN OTOMATIS
}

\author{
Rosnani Ginting, ${ }^{1}$ Danang Nurhadi ${ }^{2}$ \\ Dosen Departemen Teknik Industri ${ }^{1}$, Mahasiswa Departemen Teknik Industri ${ }^{2}$ \\ Fakultas Teknik, Universitas Sumatera Utara \\ Jl. Almamater, Medan 20155 \\ Email : rosnani_usu@yahoo.co.id \\ Email : danhadidanang@gmail.com
}

\begin{abstract}
Abstrak. Pada saat ini, dalam masyarakat industri, khususnya, kegiatan merancang dan membuat objek adalah kegiatan yang terpisah. Proses manufaktur tidak akan berjalan dengan baik sebelum kegiatan desain selesai. Menghasilkan produk sesuai dengan kebutuhan manusia harus dicapai dari proses desain. Minat merancang ikan otomatis pengumpan adalah mengembangkan produk berkualitas baru dan menghemat waktu dalam proses kerja. Brainstorming dilakukan sebelum membuat alat pengumpan ikan otomatis. Orang yang terlibat dalam brainstorming tidak homogen dan meningkatkan ide dengan cepat tanpa tekanan. Survei dilakukan dengan menyebarkan kuesioner tertutup kepada 30 responden, kuesioner terbuka kepada 30 responden dan kuesioner AHP kepada 10 responden. Teknik sampling yang digunakan adalah simple random sampling. Dalam mendesain set Alat Pengumpan Ikan Otomatis perlu dibuat spesifikasi produk yang fokus pada kebutuhan konsumen dalam QFD bentak (Quality Function Deployment). Menghasilkan alternatif yang dilakukan dalam perancangan alat Automatic Fish Feeder Tool untuk mencapai solusi alternatif. Metode yang digunakan adalah Chart morfologi. Berdasarkan langkah-langkah rekayasa ditemukan bahwa nilai alternatif yang ada adalah alternatif terbaik dengan total biaya Rp 645.000, - lebih rendah dari biaya sebelumnya sebesar Rp 805.000.
\end{abstract}

\section{Pendahuluan}

Permintaan pasar sektor peternakan ikan di Indonesia telah meningkat akhirakhir ini. Seiring dengan pertumbuhan itu, diharapkan bahwa produktivitas juga meningkat sehingga permintaan dapat terpenuhi. Peningkatan ini dapat dilakukan dengan berbagai cara, salah satunya adalah menerapkan teknologi dalam kegiatan produksi. Teknologi di sini selain menghemat waktu, juga menghemat dalam hal penggunaan sumber daya manusia. Perkembangan teknologi telah mendorong kehidupan manusia untuk hal-hal yang lebih otomatis. Otomatisasi di semua sektor tidak dapat dihindari, jadi gunakan yang awalnya dialihkan secara manual ke otomatisasi. Tidak terkecuali hobi undangan seperti membesarkan ikan.

Kemudian dirancang alat yang memudahkan makan ikan. Sistem akan bekerja secara otomatis sesuai dengan jadwal yang telah ditentukan. Penjadwalan pakan ikan, menggabungkan perangkat keras dan perangkat lunak yang terhubung dan telah diotomatisasi. mempengaruhi hasil yang akan diperoleh.

Merancang dan membuat alat pakan ikan secara otomatis untuk merampingkan waktu dengan lebih terjadwal dan hemat energi, sehingga diharapkan peningkatan dalam hal produktivitas dan pengurangan biaya produksi.

Pengembangan alat makan ikan ini otomatis menggunakan teknologi canggih. Peralatan telah dipersiapkan untuk digunakan bahkan dengan pengembangan dan penambahan teknologi yang lebih canggih tanpa mengorbankan kualitas. QFD menyediakan sarana untuk menerjemahkan persyaratan pelanggan menjadi karakteristik teknis yang tepat untuk setiap tahap pengembangan produk dan produksi (X.X.Shen et.all, 2000). Quality Function Deployment (QFD) adalah teknologi yang memungkinkan kunci untuk rekayasa konkuren. Ini digunakan untuk menyebarkan kebutuhan pelanggan ke manufaktur (Robert L. Armacost, et.all, 1994). Penyebaran fungsi kualitas (QFD) 
adalah alat utama untuk aplikasi rekayasa konkuren dan penerapan manajemen kualitas total (TQM) (Cengiz Kahraman, , et.all, 2004).

Dalam implementasinya, kita membutuhkan metode menghasilkan ide yang berguna untuk mencari alternatif dalam desain produk untuk menarik dan memuaskan pelanggan.

\section{Pembahasan}

\subsection{Brainstorming}

Diperlukan untuk menghasilkan desain produk yang kreatif dan inovatif. Untuk melakukan brainstorming, perlu dibentuk kelompok yang terdiri dari pemimpin sebagai fasilitator. Dengan tidak lebih dari 30 menit dan suasana santai, itu akan menghasilkan gagasan utama sebagai kesimpulan dari kelompok. Produk desain yang sesuai dengan kebutuhan konsumen merupakan faktor penting dalam merancang suatu produk. Langkah-langkah brainstorming adalah sebagai berikut:

a. Membentuk Kelompok dan Pemimpin Menetapkan

b. Menginformasikan

Aturan

Brainstorming

Pemimpin Kelompok Mengancam Pernyataan Masalah Awal

c. Setiap Anggota Diberi Waktu Tenang Selama 30 Menit untuk menggali ide

d. Menulis ide sendiri dan Tanggapan Diberikan

e. Kumpulkan Kertas-Kertas dan Setelah Periode Lakukan Evaluasi

Berdasarkan hasil brainstorming, dapat disimpulkan rancangan spesifikasi produk yang akan dibuat, antara lain:

Sebuah. Produk bahan utama adalah plastik.

a. Produk tinggi adalah 1 meter.

b. Warna produknya hijau.

c. Bentuk produknya adalah kotak.

d. Produk tambahan adalah pemangkas.

e. Dimensi produk saluran 1 meter f. Kapasitas pakan pakan ikan adalah $2 \mathrm{~kg}$. g. Produk sumber energi adalah panel surya.

\subsection{Survey market}

Teknik pengambilan sampel yang akan digunakan adalah non-probability sampling Judgment sampling. Teknik pengambilan sampel adalah teknik pengambilan sampel di mana anggota populasi yang telah menjadi anggota sampel adalah populasi pemilik kolam ikan dan akuarium.

Berdasarkan kuesioner yang telah dibagikan menggunakan simple random sampling di antara peringkat yang diperoleh kelompok produk I dengan produk pesaing. Tabulasi hasil penilaian dari daftar tertutup dapat dilihat pada Tabel 3.1.

Table 3.1. Tabulations
\begin{tabular}{|l|l|}
\hline Ranking & Product \\
\hline 1 & Group I \\
\hline 2 & Competitor 1 \\
\hline 3 & Competitor 2 \\
\hline 4 & Competitor 3 \\
\hline
\end{tabular}

\subsection{Step problem into sub-problems}

Menemukan masalah yang muncul pada bentuk keinginan konsumen, dimensi, warna, bahan, dan fungsi tambahan. Dari masalah yang muncul akan dicari dari subproblem yang ada. Untuk itu ada tiga langkah yang dapat dilakukan agar masalah ini terurai menjadi sub-masalah, yaitu klasifikasi tujuan, klasifikasi fungsi, dan penentuan kebutuhan.

Melalui klarifikasi tujuan dapat subsub dari tujuan desain secara umum dan menunjukkan hubungan antara setiap tingkat menggunakan pohon tujuan. 


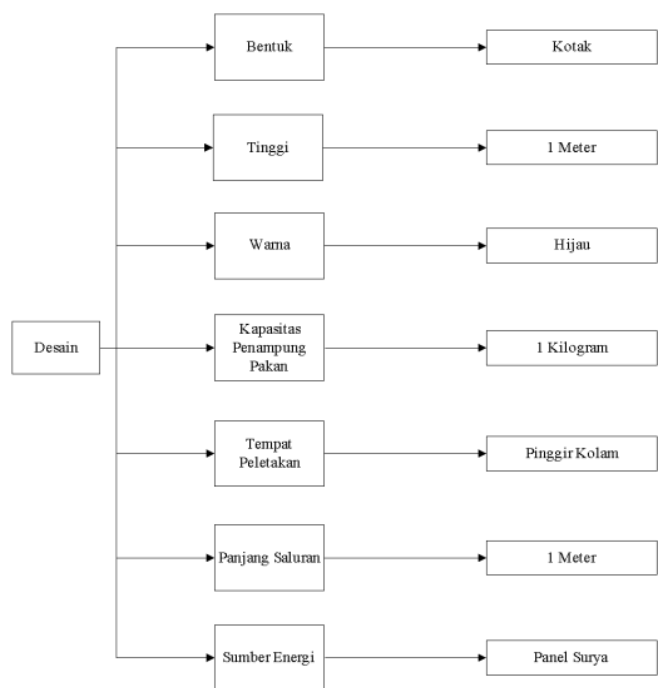

Figure 3.1.Objectives Tree

\subsection{Step sub problem into sub solutions}

QFD adalah cara untuk meningkatkan kualitas barang atau jasa untuk memahami kebutuhan konsumen dan kemudian menghubungkannya dengan kondisi teknis untuk menghasilkan barang atau jasa pada setiap tahap pembuatan barang atau jasa yang dihasilkan. Sub solusi berasal dari penyelesaian masalah yang terjadi, termasuk pemilihan atribut untuk produk alat pengumpan ikan otomatis, yang dilakukan dengan menggunakan langkah

Nigel Cross, dengan tetap mempertahankan keunggulan yang telah dimiliki dan meningkatkan kualitas produk. Ada 3 langkah untuk melakukan sub solusi ke dalam solusi, yaitu pembuatan alternatif, evaluasi alternatif, dan komunikasi (meningkatkan perincian).

Sub-masalah dapat dibuat dengan membuat QFD untuk mengetahui karakteristik produk.

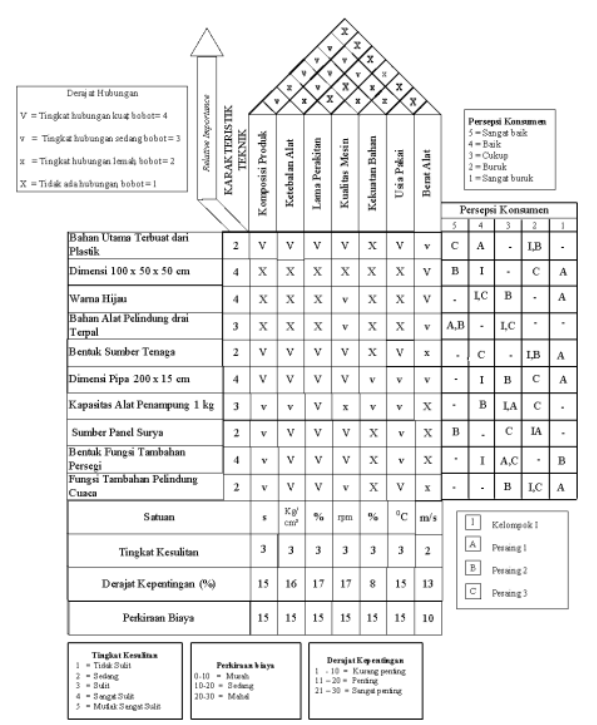

Figure 3.2. Quality function Deployment (QFD) Tool Fish Feed Automatic

1. Langkah solusi sub solusi untuk

Kombinasi yang teridentifikasi dari semua solusi desain yang mungkin dari bagan morfologi.

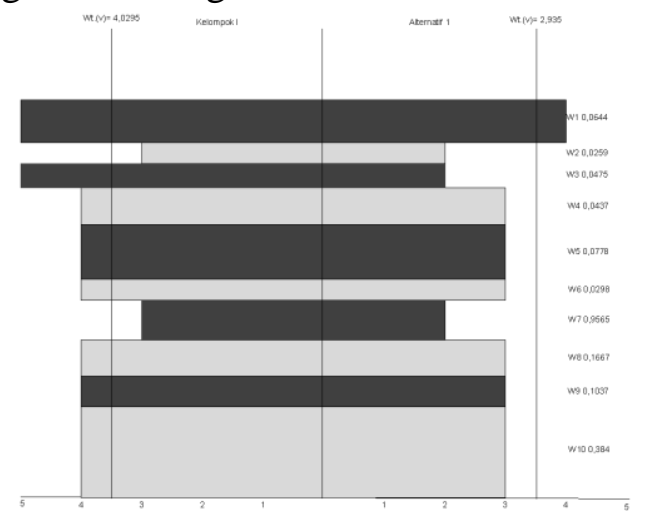

Figure 3.3 Profile Value Comparison of Alternative 1 and 2

Dari perhitungan gap lebar antara kelompok dan alternatif, kelompok simpang sirip lebar $(0,033)$ lebih kecil dari jeda lebar Alternatif $1(0,578)$ sehingga produk yang dipilih adalah kelompok produk I. Dari grafik gantt dapat dilihat bahwa bobot terbesar yang terkandung dalam W8, yang merupakan bahan utama alat. Sedangkan bobot terkecil adalah W2, yang merupakan bagian dari tinggi. Grup I cenderung lebih stabil daripada alternatif 1 karena penyimpangan jauh, adalah W10 (fungsi tambahan) yang memiliki peringkat kepentingan 1,536. 


\subsection{Step sub problem into sub solutions}

Solusi yang diambil dalam desain ini adalah:

1. Pakan ikan alat akan dirancang memiliki karakteristik sebagai berikut:

a. Sebuah. alat pakan ikan memiliki dimensi $50 \times 50 \times 100 \mathrm{~cm}$

b. pakan ikan alat memiliki warna hijau

c. pakan ikan alat memiliki bentuk kotak

d. pakan ikan alat memiliki wadah tubulan

e. alat pakan ikan yang terbuat dari plastik

f. pakan ikan alat memiliki tempat bertelur di samping

g. pakan ikan alat memiliki banyak pakan jatuh 1 meter

h. pakan ikan alat memiliki terpal pelindung

i. pakan ikan alat memiliki satu kali makan

j. pakan ikan alat memiliki kekuatan dari panel surya

k. Harga yang akan dikeluarkan dalam proses mendesain suatu produk adalah Rp 645.000

\section{Kesimpulan}

berikut:

Kesimpulannya adalah sebagai

1. Karakteristik produk pakan ikan yang secara otomatis berasal dari desain tujuan adalah ikan pengumpan memiliki dimensi $50 \times 50 \times 100 \mathrm{~cm}$, hijau, berbentuk kotak, wadah tubular dengan kapasitas penyimpanan pakan 1 kilogram, plastik, tempat peletakan alat tepi kolam, jarak jatuh pakan 1 meter, memiliki terpal pelindung, memiliki waktu memberi makan (timmeri) dan tenaga dari panel surya

2. Survei yang dilakukan dengan menyebarkan kuesioner meliputi 30 responden, kuesioner terbuka untuk 30 ahp responden dan kuesioner kepada 10 responden.

3. Penentuan fungsi alat pengumpan ikan otomatis adalah transformasi input dan output dengan blackbox. Maka fungsinya dibagi menjadi sub-fungsi yang esensial. Diagram blok menunjukkan interaksi antara sub-fungsi.

4. Menentukan kebutuhan alat alat pakan ikan secara otomatis kelompok pertama adalah untuk menciptakan tingkat generalitas yang berbeda dan solusi desain yang dapat diberikan produk alternatif, menentukan tingkat generalitas utama, mengidentifikasi atribut kinerja produk yang diperlukan dan menentukan informasi yang dibutuhkan.

5. untuk atribut produk ikan feeder dapat dibagi menjadi beberapa bagian. Atribut utama dari pengumpan ikanadalah desain produk, bahan, dan fungsi tambahan. Atribut desain dibagi menjadi atribut sekunder yaitu dimensi, alat warna, alat bentuk, bentuk umpan, dan sumber energi. Bahan atribut dibagi menjadi atribut sekunder bahan alat, bahan pelindung, dan bahan kontainer. Atribut fungsi tambahan dibagi menjadi atribut sekunder dari waktu makan.

6. Untuk QFD ditemukan bahwa teknik yang memiliki nilai tertinggi adalah komposisi produk dengan 3 tingkat kesulitan, tingkat minat 17 dan perkiraan biaya 15. Hal ini menunjukkan bahwa komposisi produk memiliki pengaruh yang besar terhadap pembuatan produk.

7. Dari gambar gantt chart, kesimpulan komprehensif gap group I $(0,033)$ lebih kecil dari jeda lebar Alternatif $1(0,578)$ sehingga kelompok produk terpilih I dengan penyimpangan terbesar yang ditemukan pada W8 adalah bahan utama alat. Sedangkan bobot yang terkecil adalah W2 yang merupakan bagian dari alat yang tinggi.

8. Berdasarkan langkah-langkahnya menunjukkan bahwa nilai rekayasa alternatif yang ada adalah alternatif terbaik dengan total biaya Rp 645.000, - 
lebih rendah dari biaya sebelumnya $\mathrm{Rp}$ 805.000, -

\section{DAFTAR PUSTAKA}

Cengiz Kahraman, Tijen Ertay, Gülçin

Büyüközkan. 2004. A fuzzy optimization model for QFD planning process using analytic network approach. Turkey: Elsevier

Ginting, Rosnani. 2013. Perancangan Produk. Yogyakarta: Graha Ilmu

Robert L. Armacost, Paul J. Componation, Michael A. Mullens, William M. Swart. 1994. An AHP Framework For Prioritizing Customer Requirements In QFD : An Industrialized Housing Application. Florida: IEE Transactions.

X. X. Shen, K. C. Tan, M. Xie. 2000. An integrated approach to innovative product development using Kano's model and QFD. Singapore: MCB University Press 